\title{
大学院生のための高度工作実習・CDクラッシャーの製作
}

\section{Design and Fabrication of CD Crushing Device for Advanced Program of Handcraft Exercise} for Graduate Students

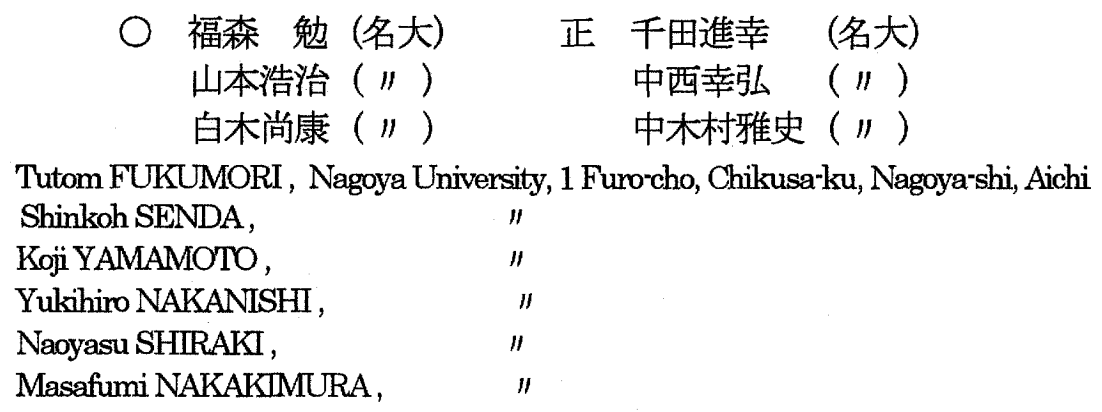

Key Wards: Fngineering Education, Product Develapment, Design

\section{1. はじめに}

我が国の産業界では，高機能で高付加価值の製品を低コス トで製造する国際競争力が強く要求される．技術者教育におい ては，高い創造性を持ち，さらに安全，地球環境，経済性など についても考慮できる人材の育成が求められている.このよう な状況の中で実習は，座学で体験できない実践的な力をつける トレーニングの場と考えられる.

名古屋大学機械工学系専攻では，学部生から大学院生まで各 レベルに応じた実習を企画し，導入コース，基本コース，アド バンスコースの順で実施している. アドバンスコースでは，平 成 14 年, 15 年度ミ二旋般製作, 平成 15 年, 16 年度タップ機 能付きハンドドリルの製作をおこなった，特に平成 16 年度以 降は，それまでの参加グループが同じものを製作する画一的な 実習内容から，参加グループごとに機能やデザインに自由度を 大きく持たせた創造的なもの一と課題テーマを改めた．さらに 本年度からは，創造性に加えてコストを考えた実習人と発展さ せるため実習課題を変更し「CD クラッシャー」製作を試みた。 以下にその詳細を述べる.

\section{2. 実習の特徵之目的}

本実習は次のような特徴と目的を持っている.

(1) 専門科目の履修と実習等の基本コースを終了した大学院生 を対象とするものであり，高度で総合力を要する内容とする. 機械工学系技術者に必要な「考え」，「作り」，「動かす・使 う」能力を実践させる.

(2)創造性の向上を目指して，独創的な機構やアイデアが発揮 しやすいように形状や機構などの自由度の幅を大きく設定し ている.

(3)発想一設計一加工一組み立て (完成)までの間に起こりうる 各種の問題について，その原因の的確な把握とその解決のため に取り組むアプローチを通して，参加学生各自にモノづくりに 対する姿勢と自主性を求める.

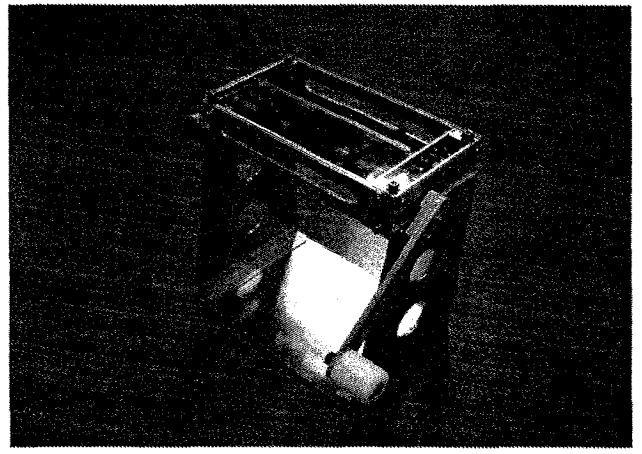

Fig.1 Prototype of CD crusher

(4) グループによる共同作業を通して協調性を養うと共に，各 自が分担部分を全うする責任感を要求する.

(5) 実用性・安全性・生産性・経済性・廃棄時の分解性なども 考慮した商品価値のある製品「CDクラッシャー」を作るこ とで技術者としての高い意識と実力を養う。

\section{3. 実習概要}

本実習では，著者らが試作したCDクラッシャー（Fig 1) を参考として提示するが，CDを切断する機構や形状は全く別 の製品を創造（考案）して製作してもらうことを課題としてい る. 使用する材料は一定の範囲で自由を認めるが，刃部の材質 については炭素鋼 S55C 丸棒を使い，切り歯が回転して切断す る構造だけは指定した，指定の理由は，熱処理についても体験 してもらい，刃部を自作させるためである. 実習指導は，数名 からなるグループ（構成は同一研究室）を対象とし，延べ20 時間に設定している，設計レビュ一を技術職員と行ない製作上 に問題なければ図面を作成する，製作実習は，沉用工作機械おう よび CAD/CAMマシニングセンタなどの利用も含めている. 各日の実習後に，使用材料の種類や大きさ，作業時間，次回担 当者への申し送り事項などを記載した作業日誌を付けさせる. 完成後にこれをもとに製作経費を計算させ提出させる. 


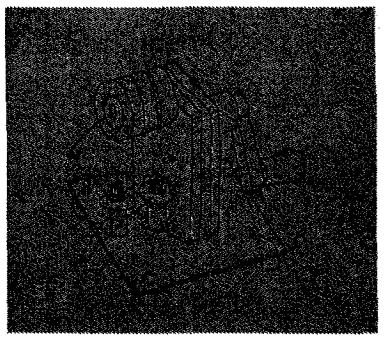

(a) Sketch

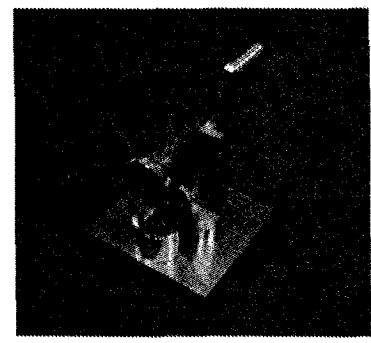

(b) Finished product
Fig. 2 A unique $C D$ crusher presented by students

\section{4. 実習の実施}

本実習は，7月から 10 月にかけて実施した。参加者は4研 究室, 6チーム，22名の大学院生で，その全員が基本コース の実習の受講者である.

指導体制は，設計レビュ一時は複数職員で対応し，実技は 6 名の技術職員で 2 名ずつのローテションで害習をおこなった。

6チームがそれぞれ違う機構を用いてCDの切断をおこなう 方法を考えて製作している．以下に1グループの作品の例を紹 介する.

Fig 2 は学生がアイデアをスケッチ画にし，それをもとに図 面化し製作したCDクラッシャーである，偏心軸にCDを取り 付けハンドルを回すことで切断する簡単な機構である. 表 1 に 製作時間の内訳と材料費を示す。

Tablel Auexample of practice hours and material oost

\begin{tabular}{|c|c|}
\hline & Hours \\
\hline Cenebration & 2.0 \\
\hline Design review & 2.5 \\
\hline General machinetools & 14.5 \\
\hline CAD/CAM & 1.5 \\
\hline Machiningcenter & 3.5 \\
\hline Hand finishing & 2.5 \\
\hline Total & 26.0 \\
\hline Material cost & $¥ 4,070$ \\
\hline
\end{tabular}

\section{5. アンケート結果}

実習終了後におこなったアンケート結果の一部を Fig 3に示 す.「創造性が発揮でき実践的な実習ができましたか?」との 問いに程度の差はあるが $95 \%$ 学生ができたと回答している. 一方でできなかったとした学生が5\%いる．また，「授業との 関係で技術の理解が深まったか?」との問い程度の差はある が $100 \%$ 学生が深まったと回答している. その他の設問の回 答をみてもほぼ同様の結果であり，本実習はおうおむ水受講者に 満足を与えたことが判明した。

以上のアンケート結果から，「CDクラッシャー」の製作は 上級コースとして相応しい課題であったと判断される.

\section{6. 成果発表会}

全日程終了後、担当教員，技術職員，およひ学生全員参加に
よる成果発表会を開いている，グループによる自己評価プレゼ ンテーション，および実演をおこない製品としての機能および 商品価值などを競い合う，学生たちが出展作品を見合い，相互 評価することはモノづくりには大いに意義がある.

\section{7. まとめ}

著者らはこれまで創成型モノづくり実習プログラムを開発し， 常に試行錯誤しながら新しい企画を取り入れ発展させてきた。 本年度は製作課題を一新し，特記すべき点は，受講者に製作時 間や材料費まで意識した設計を求めながら創意工夫を発揮でき るよう配慮したことである，限られた時間と費用で効果的な害 習が企画・実施できたと考えている. 今後一層の企画の改良を 加えて高度工作実習に相応しいプログラムを構筑していきたい．

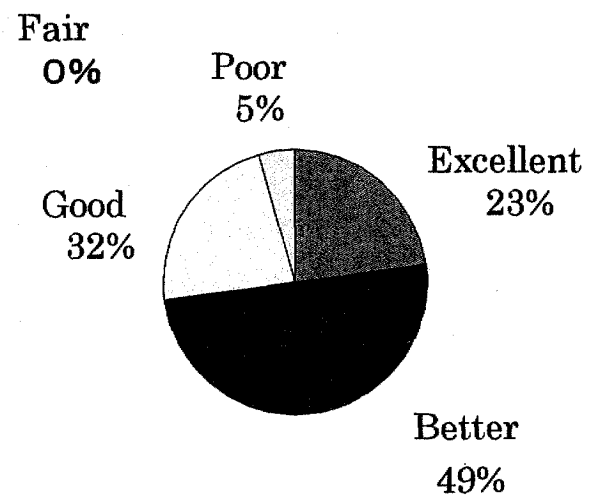

Q1: Could you creatively exercise the handcraft and improve your skill? Fair and Poor

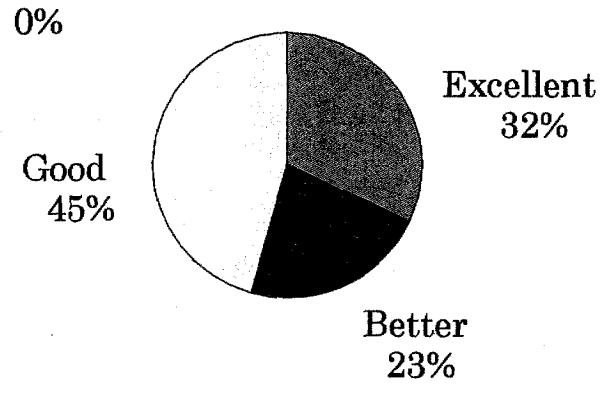

Q2: Did this course improve your understanding of technologies give in lectures?

Fig.3 Student's comments after completion of practice

\section{謝 辞}

本論文で紹介した実習は平成 18 年度, 名古屋大学大学院工 学研究科機械系教室の協力を得て実施したものです，関係者の 皆様に厭く御礼申し上げます.

また本論文の執筆にあたり，哌切なる指導をいただきました 同工学研究科 創造工学センター長 佐藤一雄教授に心より感謝 いたします。

\section{文献}

(1) Senda,S.Advanoed Program of Handcrafts Exercise for Graduate Students (Development of Lap top Lathe and Evaluation of Execution), Transactions of the Japan Society of Mechamical Engineers, Series C,Vol. 71, No. $710(2005)$, pp. 235-240 